\title{
スポーツと離断性骨軟骨炎
}

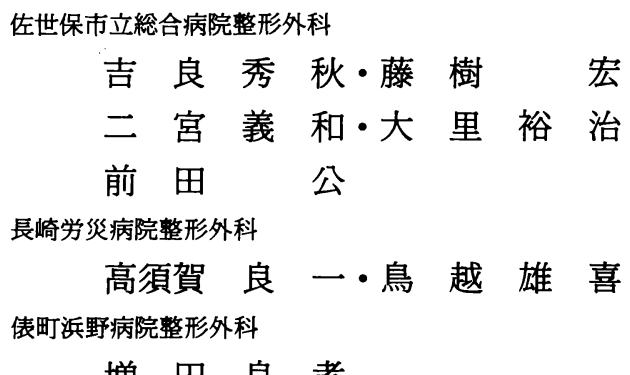

\section{Osteochondritis Dissecans of the Femoral Condyle of Patellofemoral Joint} by

Hideaki Kira, Hiroshi Fujiki, Yoshikazu Ninomiya, Yuji Ohsato and Hiroshi Maeda

Department of Orthopaedic Surgery, Sasebo City General Hospital

\author{
Ryouichi Takasuga and Takayoshi Torigoshi \\ Department of Orthopedic Surgery, \\ Nagasaki Rosai Hospital \\ Yoshitaka Masuda \\ Department of Orthopedic Surgery, \\ Tawaramachi Hamano Hospital
}

The most common site for osteochondritis dissecans of the knee is the medial femoral condyle. Seldom reported localizations are the lateral tibial condyle and the inferior patellar pole.

Osteochondritis dissecans of the femoral condyle of the patellofemoral joint appears to be extremely rare, and we report three new cases.

To our knowledge, this is the first report of patients with osteochondritis dissecans of the femoral condyle of patellofemoral joint.

These three patients were all athletes.

\section{症例}

$$
\text { はじめに }
$$

最近経験した成長期スポーツ障害によると思われる 離断性骨軟骨炎（以下OCD） 4 例を報告し，本症の 発生について検討する。
症例 114 才，女性

現病歴：11 才より剣道部に所属, 週平均 10 時間の 練習をしてきた。この間, 左足関節 supination 強制位 での捻挫を数回経験している. 13 才頃より左足関節の 痛みがしだいに增強してきたため, 平成 3 年 8 月某医 
受診X線像で左足関節の異常を指摘され, 平成 3 年 9 月当科を訪れた.

初診時現症および経過：身長 $152 \mathrm{~cm}$, 体重 $59 \mathrm{~kg}$ と肥 満があったが，左足関節に腫脹なく可動域制限も認め なかった，左足関節正面 $\mathrm{X}$ 線像で距骨内側関節面の不 整像を認め(図 1)，C Tでも遊離した骨片の存在を確 認できた (図 2 ). 同部のMR I T 強調像では距骨内側 に低信号域を認める(図 3 )。これらより距骨の骨軟骨 骨折またはＯCDと診断しＰＴＢ免荷装具で約 3 力月

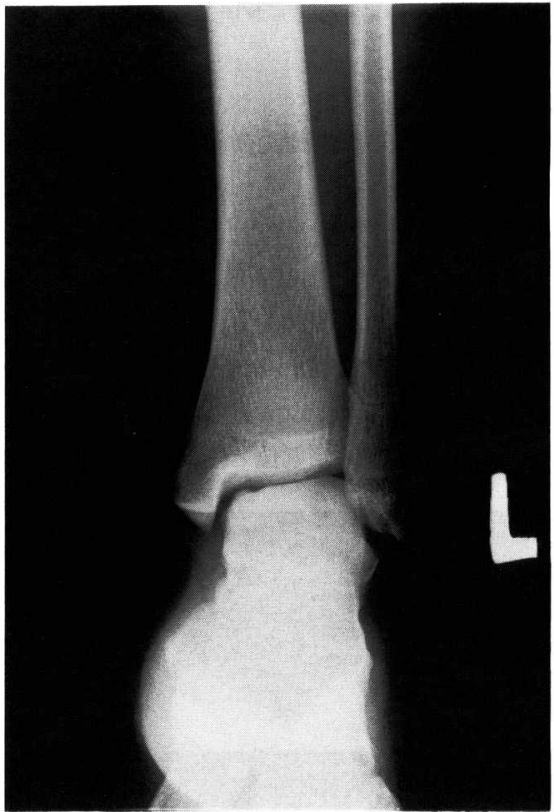

図 1，距骨内側関節面の不整像を認める. (症例 1 )

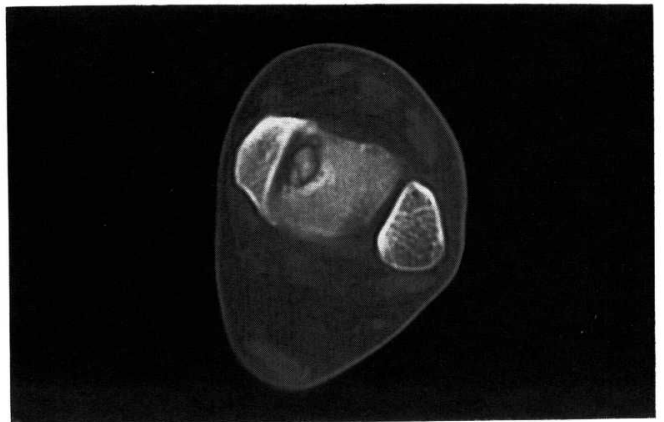

図2、遊離骨片はC T 像ではっきりしている。
間経過をみていたが, 症状軽快しないため平成 3 年 12 月 18 日左足関節内果を外して, 骨片摘出術を行った。 距骨内側関節面は $5 \mathrm{~mm} \times 4 \mathrm{~mm}$ の範囲で下面に骨が付着 した状態で浮き上がっており一部に軟骨が連絡を保っ ていた。これを摘出し, 露出した骨にドリリングを行 った。摘出骨片の病理組織像では, 軟骨の構造はほほ 正常に保たれていたが, 軟骨下骨組織には empty

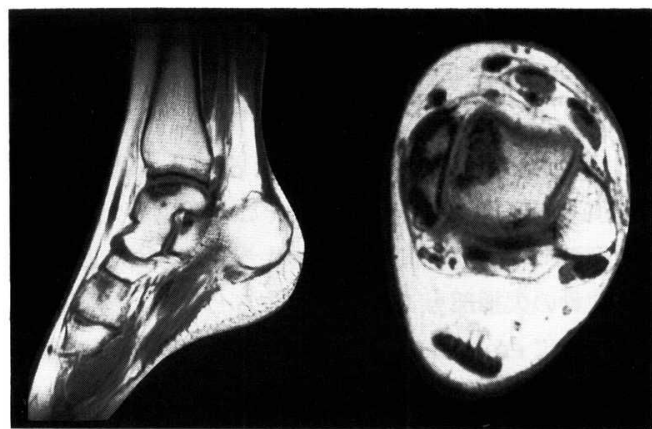

図 3. 同部の MRIT 強調像では距骨内側に低信号域を認 める。

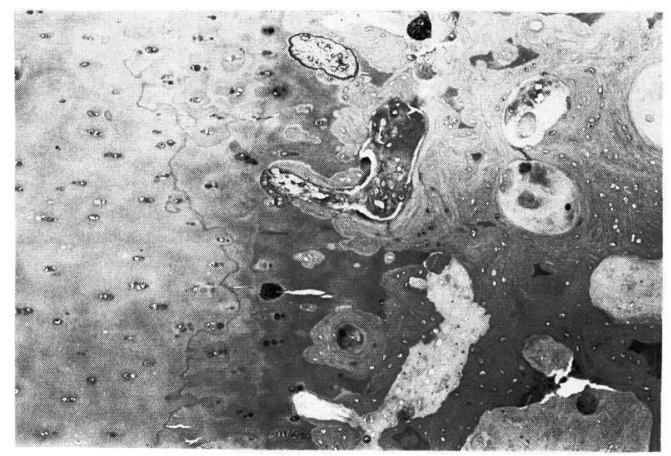

図 4.摘出骨片の病理組織像 $\mathrm{HE}$ 染色 $\times 40$ 軟骨の構造はほほ正常に保たれていたが軟骨下骨組 織には empty lacunae が存在し, 骨髄組織は壊死に 陷っていた。

lacunae が存在し，骨組織は壊死に陥っていた(図 4 )。 術後 5 力月の現在歩行時の痛みは消失している.

症例 215 才, 男性

現病歴：11 才よりバスケットボール部に所属, 週平 均 15 時間練習をしていた。 12 才の時サッカーをして いて転倒, 某医で左膝関節血腫を指摘され 2 - 3 回穿 刺してもらったが数力月で症状軽快した. 14 才になっ てバスケットの練習中に両膝関節痛と同時に右膝に 
locking 症状が出現するようになったため, 整骨院に 約 3 力月通ったが, 症状軽快しないので来院した.

初診時現症抢よび経過：身長 $163 \mathrm{~cm}$, 体重 $56 \mathrm{~kg}$. 膝 関節内血腫や apprehension sign はなく, 可動性も良 好であったが膝蓋骨軸写のX線像で両膝蓋骨は外側に 偏位して抢り（図 5 ), 膝蓋大腿関節の膝蓋骨関節面に 不整像が認められた。また右側では滕蓋骨だけでなく 大腿関節面にも異常が認められた。

C T像では大腿骨側外側関節面に陥凹がみられ（図 6), MR I でも同部に信号強度の低下が認められる (図 7 ).

O C D の診断のもとに Maquet 法による脛骨結節 部の前方内方移動術を行った。その後観察した膝蓋大 腿関節面では大腿骨側外側に骨片が遊離したと思われ る骨軟骨の欠損部とこれに対応すると思われる膝蓋骨 外側中心に erosion を認め, またこの時直径約 $1 \mathrm{~cm} の$



図 5. 膝蓋骨軸写 30 度 (上) 45 度屈曲位 (下)

(症例 2) 膝蓋骨は外側に偏位しており, 特に右側 では滕蓋骨だけでなく大腿関節面での不整像が認め られた。

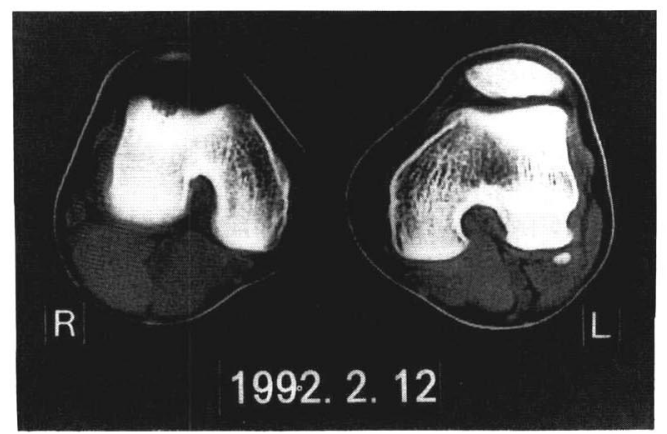

図 6. C Tでは大腿骨側外側関節面に宿凹がみられる。



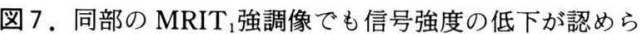
れる.

free body を摘出した. 両関節面の shaving とドリリ ングを行った.

症例 314 才, 男性

現病歴：12 才で陸上部に所属, 13 才頃より長距離走 の際右膝の痛みがあり受診。

初診時現症および経過：身長 $164 \mathrm{~cm}$, 体重 $55 \mathrm{~kg}$. 関 節水腫や apprehension sign はなかったが，膝蓋骨軸 写の X 線像で軽度の外側偏位と右側で大腿骨側外側関

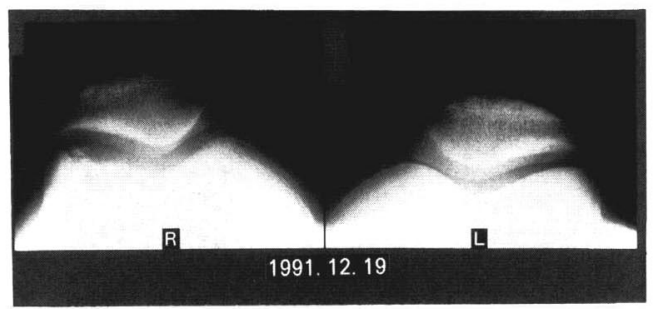

図 8. 滕蓋骨軸写の X 線像で軽度の外側偏位と右側で大腿 骨側外側関節面に異常骨片を認める。（症例 3 )

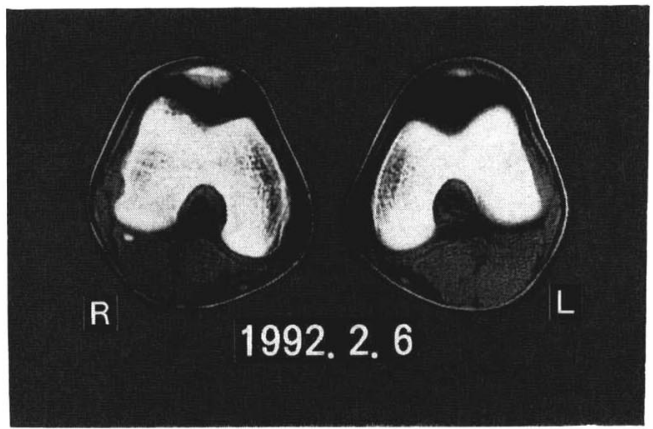

図 9.CTでも同部の OCD 確認できる. 
節面に異常骨片を認めた(図 8 )。C Tでも同部の骨欠 損像がみられた（図 9 ).

O C D の診断のもとに Maquet 法による脛骨結節 部の前方内方移動術を行った。術中所見では膝蓋関節 軟骨面は正常であったが，大腿骨軟骨面は Berndt の stage IIの病態を呈していたため, 同部のドリリング のみを行った.

症例 412 才, 男性

現病歴：11才よりバレー部に入部したあと約 4 力 月目より，右膝関節痛を自覚するようになったがクラ ブ活動を続けていたところ，症状がしだいに増強した ため受診した.

初診時現症および経過：身長 $165 \mathrm{~cm}$, 体重 $48 \mathrm{~kg}$. 膝 関節水腫はなく, apprehension signも認めなかった が滕蓋勒帯部に腫脹があり，X線像で右の patella alta と Sinding - Larsen - Johanson病が認められた

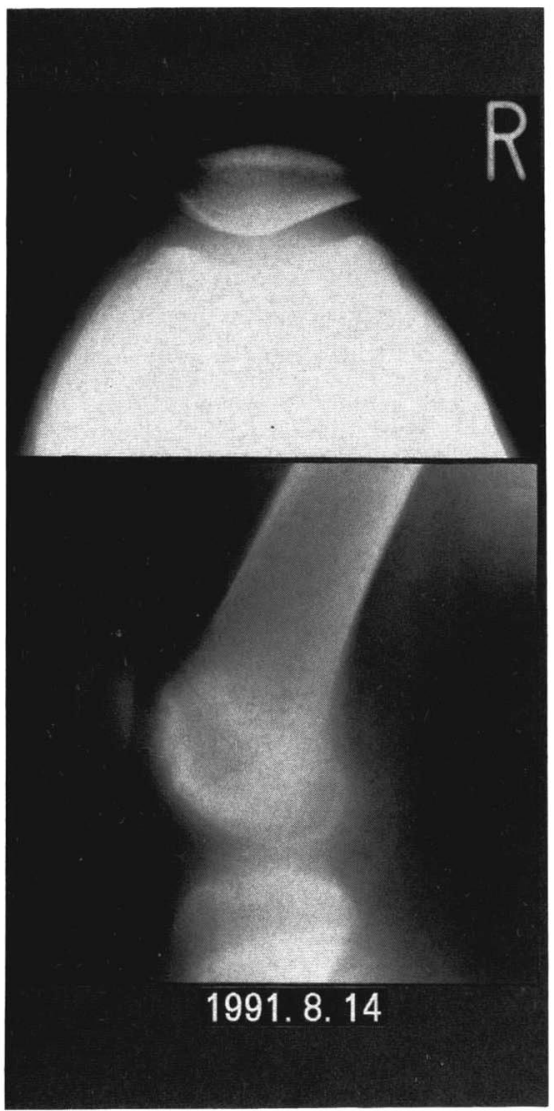

図 11. 軸写 (上) では大腿骨面の骨の変化を認め, 側面断層 (下) で大腿骨面の不整像を認め ろ.

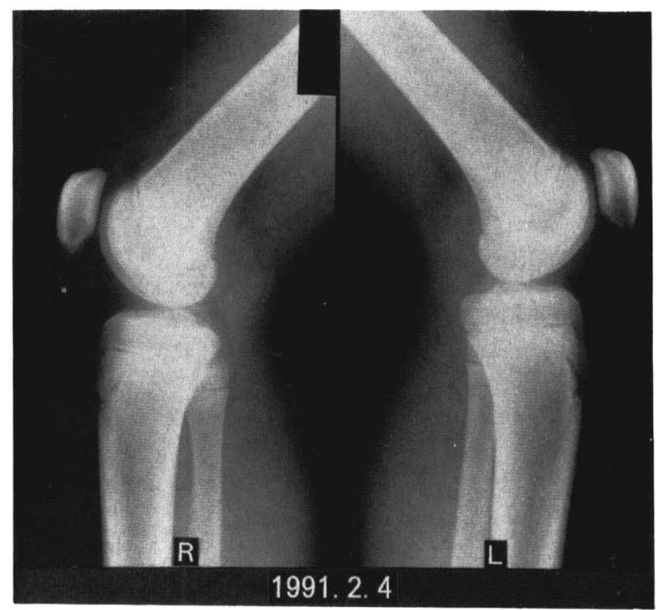

図 10. 右側に Patella alta と Sinding-Larsen-Johanson 病を認めた。（症例 4 ）

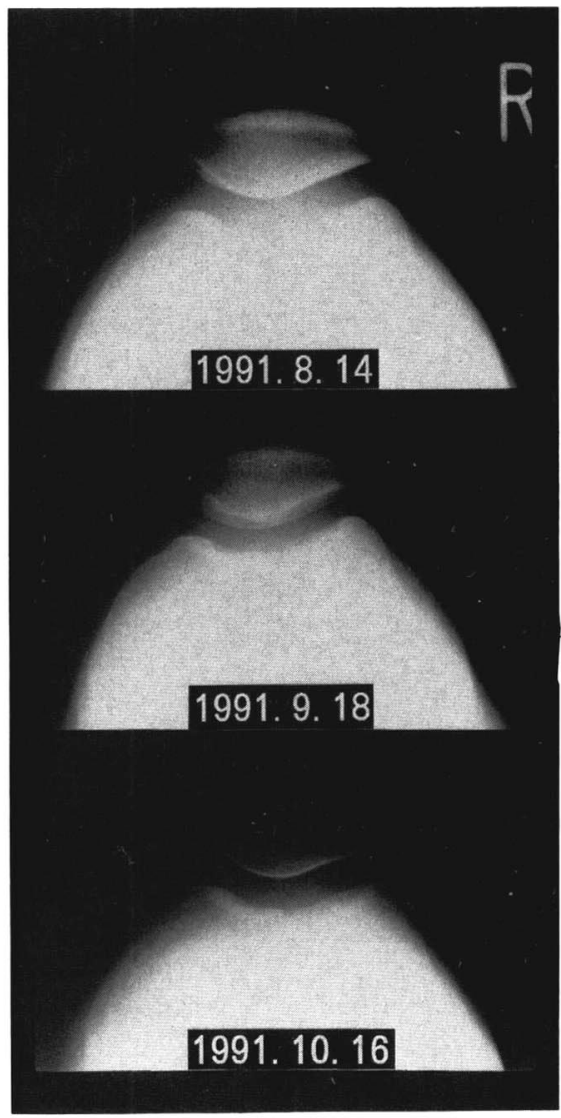

図 12.大腿骨側の軟骨下骨に硬化像を認める. 
（図 10）。軸写および側面断層像で膝蓋大腿関節面の 適合は良好であったが大腿骨外側関節面の軟骨下骨に 硬化像がみられた（図 11）。

しかし関節鏡検査では膝蓋大腿関節面の変化は認め なかった。

現在スポーツを中止し経過観察中であるが，X線学 的所見はまだ正常化していない（図 12）.

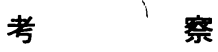

O C D は 1888 年 König が呼称して以来広く用いら れるようになり，その病態は関節軟骨下骨がなんらか の原因によって壊死に宿り母体から分離して，ときに は関節軟骨とともに剝離し関節遊離体となるものであ る.

距骨に発生するO C D 比較的少なく 1922 年 Kappisによって初めて報告されている。

1932 年 Rendu は足関節内での距骨の fragmentary fracture を報告しこれは以前報告された O C D と同 じだと述べた. 1953 年に Röden は 55 例の足関節の $\mathrm{O}$ C D を検討し，病巣が距骨の内側と外側にある場合て はその原因，予後，治療法等が異なると述べた。すな わち外側例ではすべてが外傷の既往をもち病状も高度 で予後不良であると報告した。

さらに Berndt らは距骨 O C D が主に内がえし損傷 により発生することを立証し，以来本症を骨軟骨骨折 としてとらえることが一般的となってきた。

しかし，実際上は明かな外傷歴のない症例もかなり 含まれており，熊井らは外傷歴のあるものを骨軟骨骨 折，外傷歴のないものをOCDと，両者を比較した結 果, 15 例の O C Dでは全例が女性で内側型であったと 報告している。

O C D や大腿骨頭过り症が成長期の 2 つのタイプに 発生しやすいことは良く知られている。すなわち 1 つ は性ホルモンの low levelにより起こると思われる肥 満タイプと, 非常に少ないが成長ホルモンの high levelによりひきおこされる大変急激な成長に伴う,や せでノッポタイプである.

症例 1 は，はっきりした外傷の既往のないこと，女 性であり内側型であること，やや肥満があることなど より，骨軟骨骨折より Berndt stage III（図 13）のＯ $\mathrm{CD}$ とするのが適当と考えている。そしてこれはスポ ーツ活動による局所の繰り返されたストレスが原因と 思われる。
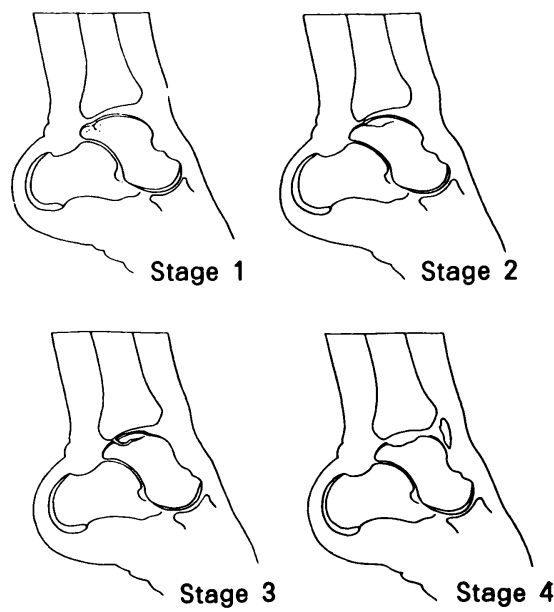

Berndt, A. L., J.B.J.S. 1959より

図 13. Berndt の分類.

膝蓋大腿関節でのＯＣＤは膝蓋軟骨軟化症や骨軟 骨々折（特に tangential osteochondral fracture）と の鑑別が必要となる。

今までの Chondromalacia patellaeの報告をみて みると, Patella 関節面の病変を内側も外側も全体と して捕らえているために, 病態の把握にいくつかの混 同がみられる。

一般に膝蓋骨の内側では圧が不十分であるための軟 骨病変であり, 外側では圧がかかりすぎるための病変 であると考えられる ${ }^{13) 16)}$. 適当な圧による pumping 作 用は, 軟骨の栄養にとって不可欠で, 軟骨に加わる圧 の低下は変性につながる. Chondromalacia patellae では central ridge から medial facetにかけて好発す るといわれているが，我々はこの圧不足による変化が Chondromalacia patellae の主病変と考えている.

一方 lateral facet の病変は, Ficatや Maquet によ れば, Patella が外側に引っ張られて lateral facet に かかる圧が上昇したために発生する軟骨の変性像であ るとされている(図 14).このような状況下で, 激しい スポーツ活動が行われれば局所は overuse, overloading となり, 複雑な病態が発生してくるものと思われ る.

今回の症例 2 ・ 3 は Patella にかかる力のバランス が，もともと外側に偏っている状態である上に，さら 


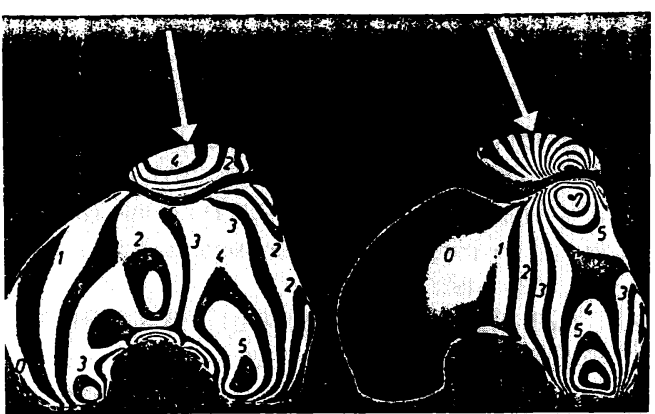

Maquet, P.G.J., Biomechanics of the Knee 1976より

図 14. Patella が外側に引っ張られるょうな状態では lateral facet の圧が上昇し, 同部に骨軟骨の変性が生 ずる.

にスポーツによるたび重なるストレスが加わって外側 顆の軟骨下骨病変が発症したものと考えられる.

また, 大腿骨外側顆の病巣の位置やX線像から osteochondral fracture とは区別できる。黄川は, Patellar pain 1 ) transverse type (横型) と 2) longitudinal type（縦型）の 2 型に分類している.つ まり膝蓋骨脱臼，亜脱臼およびFicat の言う excessive lateral pressure syndrome は横型に属し, alignment 上の問題ではなく, 大腿四頭筋の緊張により膝 蓋骨が大腿骨に対し強く圧迫牽引されるものを綐型と している.

今回の症例 $2 \cdot 3 \cdot 4$ はスポーツによる overuse syndrome であるが, 症例 2 ・ 3 においては横型と縦型が 混在しているもの, 症例 4 は alignment の異常はなか ったものの, 急激な成長期でのスポーツ障害であり, 上記因子の他に何らかの原因があった可能性も否定で きない.膝蓋大腿関節において, 膝蓋骨のOC D は時々 報告されているが，大腿骨側のＯCDはほとんど報告 されていない. 症例 1 と症例 2 の原因としては subchondral fractureにより生じたOCDとも考えるこ とができるが, 症例 3 ・4 については外傷の既往がな いばかりか, 軟骨面は全く正常であり，くりかえされ る minor traumaにより生じた OCDといえる。症例 $2 \cdot 3 \cdot 4$ は patello-femoral でのOCDであり, しか も femoral condyleのOCDでありこれらの主病変 は lateral facetに生じていたものであった.

森らは chondromalacia patellae 36 膝の中で大腿 顆部の変化を伴うものも報告している.これらは軟骨 に限られた病変（fibrillation）であるが症例 $2 \cdot 3 ・$ 4 の 3 例はすべて軟骨下骨にまで病変が及んだものと 解釈すれば, 森らの大垠顆部の変化は, 我々の症例の ようなOCDの前段階とも考えられる.膝蓋大腿関節 での骨軟骨病変の状態を知るのにC T像やMR I 像が 有用であったが，これらの検査で今後は大腿骨側の病 変の解明も期待できるであろう.

\section{ま と め}

1) スポーツ障害によると思われるOCD 4 例を報 告し, その発生原因につき考察した。

2 ）これらの内 3 例は膝蓋大腿関節における大㫰骨 側のOCDであり，非常に稀なものであった。

文献

1) Berndt, A. L.: Transchondral Fractures ( Osteochondritis Dissecans ) of the Talus, J. Bone and Joint Surg. 41-A ; 988-1020, 1959.

2) Conway, W. F. et al. : Cross-sectional Imaging of the Patellofemoral Joint and Surrounding Structures, Radiographics. 11-2 ; 195-217, 1991.

3) Dipaola, J. D. et al. : Characterizing Osteochondral Lesions by Magnetic Resonance Imaging, Artthroscopy. 7-1 ; 101-104, 1991.

4) Edwards, D. M. et al. : Osteochondritis Dissecans of Patellae, J. Bone and Joint Surg. 59-B ; 58-63, 1977.

5) Ficat, R. P. et al. : Chondromalacia Patellae, Clin. Orthop. $144:$ 55-62, 1979.

6) Ficat, R. P. and Hungerford, D. S. : Disorders of the Patello-Femoral Joint. 123-148, Baltimore, Williams \& Wilkins, 1977.

7) Harris, W. R. : The Endocrine Basis for Slipping of the Upper Femoral Epiphysis, J. Bone and Joint Surg. 32-B ; 5-11, 1950.

8) Kappis, M. : Weitere Beitrage zur traumatischmachanischen Entstehung der "spontanen" Knor pelabiosungen ( sogen, Osteochondritis dissecans ) Dtsch. Z. Chir., $171 ; 13-29,1922$.

9）黄川昭雄：スポーツと膝蓋大腿関節症, 整・災外 25 ： 1811-1820, 1982.

10) König, F. : Uber freie Körper in den Gelenken. $Z$. Chir., 27 ; 90, 1888.

11）熊井 司他：足関節離断性骨軟骨炎の病態につい て, 日整会誌, 66 ( 2 )( 3 ); S487, 1992.

12) Luisiri, A. : Osteochondritis Dissecans, Orthopedics. Radiologic Case Study. 9-3 ; 434-440, 1986.

13) Maquet, P. G. J. : Biomechanics of the Knee, Berlin Heidelberg New York, Springer-Verlag, 
1976.

14）森雄二郎他：Chondropathia patellae における滕蓋 軟骨損傷の特徴について, 整・災外 $25: 1537-1544,1982$.

15）永野重郎他：両膝蓋骨離断性骨軟骨炎の 2 例, 関西 関節鏡, 膝研究会誌, 1-1；1-3, 1990.

16）中山義人他：Chondromalacia Patellae の病態,整・ 災外 $33: 139-145,1990$.

17）岡本哲軌他：膝蓋骨に生じた離断性骨軟骨炎の 1 例，北海道整災誌，34-1. 2.; 59-62, 1990.

18) Outerbridge, R. E. : The Etiology of Chondromalacia Patellae, J. Bone and Joint Surg., 43-B ; 752-575, 1961.

19) Rendu, A. : Fracture intra-articulaire parcellaire de la poulie astraglienne, Lyon Med., 150 ; 220-222,
1932.

20) Röden, S. et al. : Osteochondritis dissecans and similar lesions of the talus, Report of fiftyfive cases with special reference to etiology and treatment, Acta. Orthop. Scand., 23 ; 51-66, 1953.

21) Sinding-Larsen, M. F. : A hitherto unknown affection of the patella in children, Acta. radiol., $1 ; 171$ 173, 1921. -1922

22）武田将毅他：両側滕蓋骨に発生した離断性骨軟骨炎 の 1 例, 関東整災誌, $21-2 ; 186-191,1990$.

23）康原正弘他：骨膜移植をおこなった膝蓋骨離断性骨 軟骨炎についての 2 症例, 関西関節鏡, 㮏研究会誌, 1-1;4-9, 1990. 